\title{
Complementary grazing of native pasture and Old World bluestem
}

\author{
ROBERT L. GILLEN AND WILLIAM A. BERG
}

Authors are rangeland scientist and soil scientist (retired), USDA-ARS, Southern Plains Range Research Station, $200018^{\text {th }}$ Street, Woodward, Okla., 73801.

\begin{abstract}
Native pasture and Old World bluestems (Bothriochloa spp.) have contrasting herbage production characteristics that suggest potential for incorporation into a complementary forage system. We compared 2 yearling beef production systems consisting of either native pasture (Native) or Old World bluestem combined with native pasture (Old World bluestem-Native) over 5 years. Crossbred steers (initial weight $257 \mathrm{~kg}$ ) grazed only native pasture in the Native system, but alternated between Old World bluestem and native pastures in the Old World bluestem-Native system. Production system had no effect on the frequency of any plant species in the native pastures $(P>0.16)$ even though stocking rate in the growing season was increased $31 \%$ in the Old World bluestem-Native system. Peak standing crop of Old World bluestem averaged $4640 \mathrm{~kg} \mathrm{ha}^{-1}$ but did not differ between the cultivars 'WW-Iron Master' and 'WW-Spar' $(P=0.16)$. Individual steer gain was higher in the Native system during the Winter $(P<0.01)$ and Early Native $(P=0.03)$ management periods, but was greater in the Old World bluestem-Native system when steers were grazing Old World bluestem in June and July $(P<0.001)$. Over the entire season, steers in the Native system gained $13.5 \mathrm{~kg} \mathrm{head}^{-1}$ more than steers in the Old World bluestem-Native system. Total livestock production was greater in the Old World bluestem-Native system (77 versus $47 \mathrm{~kg} \mathrm{ha}^{-1}, \mathrm{P}$ $<0.01$ ). Relative economic returns between the 2 systems were dependent on the marginal value of livestock gain and the relative costs of production for the 2 types of pasture. With average costs for native pasture of $\$ 17 \mathrm{ha}^{-1}$ and for Old World bluestem pasture of $\$ 62.10 \mathrm{ha}^{-1}$, the Native system was often more profitable, even though livestock production per ha was much higher with the Old World bluestem-Native system. Lower costs for native pasture and high values of livestock gain favored the Native system.
\end{abstract}

Key Words: mixed prairie, complementary forages, Old World bluestem, Bothriochloa, livestock performance

The authors wish to thank Dan Persons, Rick Hurst, Ron Charmasson, Lonnie Parsons, and Jim Bradford for livestock management and vegetation sampling. Contribution from the USDA-Agricultural Research Service. All programs and services of the U.S. Department of Agriculture are offered on a nondiscriminatory basis without regard to race, color, national origin, religion, sex, age, marital status, or handicap.

Manuscript accepted 1 Oct. 2000.

\section{Resumen}

Las praderas nativas y los zacates "Old World bluestems" (Bothriochloa spp.) tienen características de producción de forraje contratantes que sugieren un potencial para incorporarlos en sistemas complementarios de producción de forraje. Durante 5 años comparamos dos sistemas anuales de producción de carne consistentes de pradera nativa (Nativa ) o "Old World bluestem" combinado con pradera nativa ("Old World bluestem"- Nativa). Novillos cruzados (peso inicial de $257 \mathrm{~kg}$ ) apacentaron solo pradera nativa en el sistema Nativa y en el sistema "Old World bluestem'-Nativa alternaron entre "Old World bluestem" y pradera nativa. El sistema de producción no tuvo efecto en la frecuencia de ninguna de las especies de la pradera nativa $(P>$ 0.16) a pesar de que en el sistema "Old World bluestem"- Nativa la carga animal se incremento en $31 \%$ durante la estación de crecimiento. El pico de máxima producción de forraje en pie del "Old World bluestem" promedio $4,640 \mathrm{~kg} \mathrm{ha}^{-1}$, pero no difirió entre los cultivares 'WW-Iron Master' $y$ 'WW-Spar' $(P=0.16)$. La ganancia individual por novillo fue mayor en el sistema Nativa $(P<0.01)$ durante el invierno y durante los periodos de manejo tempranos $(P=\mathbf{0 . 0 3})$, pero fue mayor en el sistema "Old World bluestem"- Nativa cuando los novillos apacentaron en “Old World bluestem"en Junio y Julio (P < 0.001). A lo largo de la estación completa, los novillos en el sistema Nativa ganaron $13.5 \mathrm{~kg} \mathrm{cabeza}^{-1}$ mas que los novillos del sistema "Old World bluestem"-Nativa. La producción total fue mayor en el sistema “Old World bluestem"- Native (77 versus $47 \mathrm{~kg} \mathrm{ha}^{-1}, \mathrm{P}<0.01$ ). Los retornos económicos relativos entre los dos sistemas fueron dependientes del valor marginal de la ganancia del ganado y los costos relativos de producción para los dos tipos de sistema. Con costos promedio de $\$ 17 \mathrm{ha}^{-1}$ en la pradera nativa y de $\$ 62.10 \mathrm{ha}^{-1}$ en la pradera de “Old World bluestem", el sistema Nativa fue mas rentable, a pesar de que la producción del ganado por ha fue mucho mas alta en el sistema "Old World bluestem"- Nativa. Los bajos costos de la pradera nativa y el alto valor de la ganancia del ganado favorecieron al sistema Nativa.

Complementary forage systems combine different types of forages in an effort to overcome deficiencies in seasonal production and nutrient content that are inherent in any single forage. Major advantages of complementary forage systems include more efficient use of each individual forage, improved range condition, and higher overall stocking rates. The complementary forage system is one of the few grazing management methods that can substantially increase livestock production from forage-livestock systems in the Great Plains (Launchbaugh et al. 1978, Sims and Bailey 1995). 
Old World bluestems (Bothriochloa spp.) and native pasture have potential as components of a complementary forage system. Old World bluestems are highly productive warm-season grasses that respond well to nitrogen fertilization (Berg 1990). However, $70 \%$ of their growth occurs during the month of June and nutritive value declines rapidly (White and Dewald 1996). Old World bluestem starts rapid growth about 4 weeks later than native pasture. Native mixed prairies are dominated by warm-season grasses but also have a moderate component of coolseason grasses including annual bromegrasses (Bromus spp.) and, on sandy soils, Texas bluegrass (Poa arachnifera Torr.) Integration of Old World bluestem and native pasture could allow the capture of the short-term, high productive potential of Old World bluestem and the earlier spring growth of native prairie into a more feasible production system for stocker cattle.

Our objective was to compare steer production systems based wholly on native pasture or a combination of native and Old World bluestem pastures. Specific interests centered on the impact on the native pastures and on livestock production, the performance of 2 cultivars of Old World bluestem, and the relative net returns from the 2 systems.

\section{Materials and Methods}

This study was conducted from 1993 through 1997 at the USDA-ARS Southern Plains Range Research Station in northwest Oklahoma $\left(36^{\circ} 35^{\prime} \mathrm{N}, 99^{\circ} 35^{\prime} \mathrm{W}\right.$, elev. $630 \mathrm{~m})$. The regional climate is continental. Average annual precipitation is 560 $\mathrm{mm}$ with $72 \%$ falling during the April-September growing season. Average monthly temperatures are $2.3^{\circ} \mathrm{C}$ in January and $28^{\circ} \mathrm{C}$ in July. Minimum and maximum recorded temperatures are $-27^{\circ} \mathrm{C}$ and $45^{\circ} \mathrm{C}$

Two major types of pastures were included in this study. The first type consisted of native sand sagebrush (Artemisia filifolia Torr.)-mixed prairie growing on deep sandy soils on gently undulating, stabilized dunes (Berg 1994). Pratt soils (sandy, mixed thermic Psammentic Haplustalfs) were on the lower slopes and more level areas, and Tivoli soils (mixed, thermic Typic Ustipsamments) occurred on the upper slopes. A mixture of tall, mid, and short warm-season grasses dominated the vegetation. Applications of 2,4D (2,4-dichlorophenoxyacetic acid) in the 1970's and 1980's had reduced canopy cover of sand sagebrush to less than $5 \%$ on the study pastures. All study pastures were contiguous.

The second pasture type was a monoculture of the introduced grass Old World bluestem (Bothriochloa ischaemum L.). Two different cultivars of Old World bluestem, 'WW-Spar' and 'WW-Iron Master,' were studied. The WW-Spar pastures were seeded in 1980 and the WWIron Master pastures were seeded in 1983. Both cultivars were seeded on Pratt fine sandy loams. Prior to seeding to Old World bluestem, these fields supported monocultures of various forage grasses or short-term (3 year) production of winter wheat since 1940. Old World bluestem pastures were located within $1 \mathrm{~km}$ of the rangeland pastures.

The Old World bluestem pastures were burned each spring in early to mid April to remove dead standing forage. We did not burn these pastures in the spring of 1996 because of low precipitation and high fire danger throughout the spring. Nitrogen was applied at a rate of $67 \mathrm{~kg} \mathrm{~N} \mathrm{ha}^{-1}$ as ammonium nitrate in the third or fourth week of April each spring. Broadleaf weeds, primarily horseweed [Conyza canadensis (L.) Cronq.], were controlled with $0.56 \mathrm{~kg} \mathrm{ha}^{-1} 2,4-\mathrm{D}$ on 13 June 1995 and with $0.84 \mathrm{~kg} \mathrm{ha}^{-1} 2,4-\mathrm{D}$ on 13 June 1997. No cultural practices were applied to the rangeland pastures.

Experimental treatments consisted of 2 basic production systems. The first system contained only native pasture (Native). The second system combined Old World bluestem and native pasture (Old World bluestem-Native). Within the Old World bluestem-Native system, there were 2 subsystems differing only in the variety of Old World bluestem they contained. One sub-system contained WW-Spar and the second contained WW-Iron Master. There were 2 replications of each of the 3 systems or subsystems for a total of 6 experimental units. The experimental units for the Native treatment were approximately 20 ha in size. Each experimental unit for the Old World bluestem-Native treatments consisted of a 20-ha rangeland pasture matched with a 2.6-ha Old World bluestem pasture.

The grazing season was divided into 4 periods. Average dates for these periods were: a) Winter, 21 December to 15 March (84 days); b) Early Native, 15 March to 9 June (86 days); c) Old World Bluestem, 9 June to 30 July (51 days); and d) Late Native, 30 July to 31 August (32 days). The total grazing season averaged 253 days. In the Native system, steers grazed native pasture for the entire grazing season. In the Old World bluestem-Native system, steers grazed Old World bluestem during the Winter and Old World Bluestem periods and native pasture in the Early Native and Late Native periods.

Stocking rates for the native pastures were based on a moderate stocking rate of 3.9 ha steer $^{-1}$ for 320 days or about 53 steer-days ha ${ }^{-1}$ (Sims and Gillen 1999). Our stocking rate was also 53 steer-days $\mathrm{ha}^{-1}$ with a land allowance of 3.2 ha steer ${ }^{-1}$ and a grazing season of 253 days. This stocking rate should maintain plant vigor over years. Information on forage and livestock production on Old World bluestem over a range of stocking rates is not available. However, the stocking rate chosen for this study has been tested for this environment and determined to be sustainable over years (Berg and Sims 1995).

Six yearling beef steers were allocated to each experimental unit for the Native system and 12 steers were allocated to each Old World bluestem-Native unit. Steers were typical crossbred yearlings (Bos taurus x B. indicus, maximum 1/8 B. indicus) originating in north-central or south Texas. Steers were randomly allocated to treatment groups such that average initial weights were equal among experimental units. Weight classes within the original steer herd were proportionately represented in the treatment groups. Initial weights averaged $257 \mathrm{~kg}(\mathrm{SD}=12$ $\mathrm{kg}$ ). Steers were weighed on each management date after being held for 18 hours without feed or water. Steers were implanted with Synovex-S ${ }^{1}$ (Ft. Dodge Animal Health, Overland Park, Kan.) at the start of grazing and again in early May. We fed a $38 \%$ crude protein cube to the steers at a rate of $1.7 \mathrm{~kg} \mathrm{head}^{-1}$ day $^{-1}$ from the start of grazing until about mid April. Actual practice was to feed $3.9 \mathrm{~kg} \mathrm{head}^{-1}$ of supplement 3 times per week. Steers were treated for internal parasites with Ivomec ${ }^{1}$ (Merial Limited, Iselin, N.J.) in early May. They had unlimited access to block salt. All procedures for animal care and management were in accordance with accepted guidelines (Consortium 1988).

In the winter of 1994, all steers on the Old World bluestem-Native units were grouped together as a single herd and grazed Old World bluestem pastures that were not in the study for 55 days (49\% of the Winter period). In 1996, severe

${ }^{1}$ Names are necessary to report factually on available data, however, the USDA neither guarantees nor warrants the standard of the product, and the use of the name by USDA implies no approval of the product to the exclusion of others that may also be suitable. 
drought in the early growing season delayed grazing on the Old World bluestem until June 21. Abundant precipitation in July and August resulted in high production of Old World bluestem and the steers were left on the Old World bluestem units until the end of the grazing season, August 28. This eliminated the late summer grazing period on rangeland for the Old World bluestem-Native steers. Because of these inconsistencies in grazing management, steer gains for 1994 and 1996 were excluded and only gains from 1993, 1995, and 1997 were used in the analyses.

Frequency sampling was conducted in the native pastures to determine the effects of production system on plant species composition. Four transects consisting of 50 quadrats $\left(0.1 \mathrm{~m}^{-2}\right)$ were located in each pasture for a total of 200 quadrats per pasture. The distances between transects and quadrats were calculated to allow uniform spacing across the pastures and quadrats were located by pacing. The first sample was taken in October 1993, at the end of the first year of treatment. Presence or absence in the quadrats was recorded for all plant species. A second sample was taken in late September 1996, after 4 years of treatment. Presence or absence of 25 plant species was recorded. The species list for the second sample was based on the 25 most common plant species from the first sample.

Peak standing crop of Old World bluestem was determined at the end of the summer grazing period for Old World bluestem. One plot measuring 1.3 x $4.9 \mathrm{~m}$ was harvested with a sickle bar mower at a height of $7 \mathrm{~cm}$ within each of 5 exclosures per experimental unit. The exclosures were moved each year. Forage samples were dried at $60^{\circ} \mathrm{C}$. Only data from the years 1993 and 1995 to 1997 were included in the analyses because data from 1994 were lost.

Frequency of plant species within the rangeland units was analyzed with a completely randomized analysis of variance with repeated measures (Milliken and Johnson 1984). Production system was the whole plot independent variable and year was the repeated independent variable. The variance due to production system was further partitioned into orthogonal contrasts of Native versus Old World bluestem-Native and WW-Spar versus WW-Iron Master (within Old World bluestem-Native). A probability level of $\mathrm{P}$ $=0.10$ was used to declare significant treatment effects.

Peak standing crop of Old World bluestem was analyzed with a completely randomized analysis of variance with repeated measures. Variety of Old World bluestem was the whole plot independent variable and year was the repeated independent variable.

Steer gains were analyzed as a completely randomized analysis of variance with repeated measures. Production system was the independent variable and year was the repeated variable. Gain per head was analyzed separately for each management period and for the entire season. Gain per ha was analyzed for each forage type within production system and over all production systems.

The main focus of the economic analysis was to determine the factors that favor one production system over the other in terms of net returns (NR).

$\mathrm{NR}=\mathrm{GI}-\mathrm{LiP}-\mathrm{LiVC}-\mathrm{LaC}$,

where,

GI $=$ gross income

$\mathrm{LiP}=$ livestock purchase costs

LiVC = livestock variable costs of production

$\mathrm{LaC}=$ land costs.

These terms can be rewritten as

GI $=$ Head $\mathrm{x}$ Sale Weight $\mathrm{x}$ Sale Price

LiP $=$ Head $\mathrm{x}$ Purchase Weight $\mathrm{x}$ Purchase Price

LiVC $=$ Head $x$ Variable costs head ${ }^{-1}$

$\mathrm{LaC}=$ Head $\mathrm{x}\left[\right.$ Cost $_{\mathrm{Np}} \mathrm{x} \mathrm{ha}_{\mathrm{Np}}$ head $\left.^{-1}\right)+\left(\right.$ Cost $_{\text {OWBp }} \mathrm{X}$ ha ${ }_{\text {OWBp }}$ head $\left.^{-1}\right)$,

where,

subscript $\mathrm{N}_{\mathrm{p}}=$ native pasture

subscript $\mathrm{OWB}_{\mathrm{p}}=$ Old World bluestem pasture.

If net returns are equal for the 2 production systems,

$$
\begin{aligned}
& \mathrm{GI}_{\mathrm{N}}-\mathrm{LiP}_{\mathrm{N}}-\mathrm{LiVC}_{\mathrm{N}}-\mathrm{LaC}_{\mathrm{N}}= \\
& \mathrm{GI}_{\mathrm{ON}}-\mathrm{LiP}_{\mathrm{ON}}-\mathrm{LiVC}_{\mathrm{ON}}-\mathrm{LaC}_{\mathrm{ON}},
\end{aligned}
$$

where,

subscript $\mathrm{N}=$ Native production system subscript ON = Old World bluestemNative system

We assumed that livestock purchase and variable costs would be similar between the systems. This assumption is warranted because the type of animal, period of ownership, and livestock management (other than grazing management) are essentially identical between systems. This reduces equation (2) to

$$
\mathrm{GI}_{\mathrm{N}}-\mathrm{LaC}_{\mathrm{N}}=\mathrm{GI}_{\mathrm{ON}}-\mathrm{LaC}_{\mathrm{ON}}
$$

Making substitutions for $\mathrm{GI}$ and $\mathrm{LaC}$ for each production system results in:

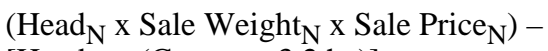
$\left[\operatorname{Head}_{\mathrm{N}} \times\left(\right.\right.$ Cost $\left.\left._{\mathrm{Np}} \times 3.2 \mathrm{ha}\right)\right]=$

$\left(\operatorname{Head}_{\mathrm{ON}} \times\right.$ Sale Weight ${ }_{\mathrm{ON}} \mathrm{X}$

Sale Price ON $)-\left\{\operatorname{Head}_{\mathrm{ON}} \mathrm{x}\right.$

$\left[\left(\right.\right.$ Cost $\left._{\mathrm{Np}} \times 1.6 \mathrm{ha}\right)+\left(\right.$ Cost $_{\mathrm{OWBp}}$ $\mathrm{x} 0.2 \mathrm{ha})]$ \}.

Equation 4 can be further simplified by assuming the 2 production systems will produce the same number of steers. This will require different total land areas. The equation can then be rearranged and reduced to:

$\left(\right.$ Sale Weight $_{N} \times$ Sale Price $\left._{N}\right)$ - $($ Sale

Weight $_{\mathrm{ON}}$ x Sale Price $\left.\mathrm{ON}\right)=(1.6 \mathrm{x}$

Cost $\left._{\mathrm{Np}}\right)-\left(0.2 \times\right.$ Cost $\left._{\mathrm{OWBp}}\right)$.

The left hand side of this equation is the difference in total sale price between a steer from the Native system and a steer from the Old World bluestem-Native system. This quantity can also be expressed as a function of the difference in weights between the 2 types of steers and the marginal value of gain:

$\left(\right.$ Sale Weight $_{N}$ x Sale Price $\left._{N}\right)$ - $($ Sale

Weight $_{\text {ON }}$ x Sale Price ON $)=($ Sale

weight $_{\mathrm{N}}-$ Sale Weight $\left.{ }_{\mathrm{ON}}\right) \mathrm{x}$ Value

of Gain

The value of gain is inversely related to the difference between the price per $\mathrm{kg}$ of lighter versus heavier animals. As the difference between the unit price of lighter and heavier animals becomes smaller, the value of gain approaches the actual sale price. As the difference in unit price increases, the value of gain decreases. The marginal value of gain is always lower than the sale price as long as lighterweight steers are worth more per $\mathrm{kg}$ than heavier-weight steers. This is the most common price structure in the U.S. beef cattle market. Substituting this alternative expression into equation 5 results in:

$$
\begin{aligned}
& (\text { Sale weight } \\
& \text { Value of }- \text { Gain }=\left(1.6 \times \text { Cost }_{\mathrm{Np}}\right) \\
& \left.-0.2 \times \text { Cost }_{\mathrm{OWBp}}\right) .
\end{aligned}
$$

Sale weights of the steers from each system are biological responses dependent on the treatments themselves. The economic advantage of one production system over the other is also dependent on 3 external factors: the value of gain, the cost of native pasture, and the cost of Old World bluestem pasture. The value of gain for the type of steers used in this study averaged $\$ 1.20 \mathrm{~kg}^{-1}$ at the Oklahoma City Stockyards from 1985 to 1995 . The minimum value of gain was $\$ 0.60 \mathrm{~kg}^{-1}$ and the maximum was $\$ 1.50 \mathrm{~kg}^{-1}$. We used these values of gain and systematically varied the cost of rangeland from $\$ 12$ to $\$ 26 \mathrm{ha}^{-1}$. At each combination of these 2 factors, we 
then solved for the cost of Old World bluestem that would equalize returns between the 2 production systems.

\section{Results and Discussion}

\section{Weather}

Precipitation during the study period was close to or higher than the long-term average with 2 exceptions (Fig. 1). The June to July period in 1994 was well below average. While precipitation totals for 1996 were above average, the distribution was highly skewed. Only $36 \mathrm{~mm}$ were received during the October 1995 to April 1996 period. This is a record low and is only $17 \%$ of the average of $213 \mathrm{~mm}$ for this period. Later that year, $488 \mathrm{~mm}(2.6$ times the average amount) were received in the months of July, August, and September.

\section{Species Composition of Native Pastures}

Production system had no impact on the frequency of any plant species in the rangeland pastures $(\mathrm{P}=0.16$ to 0.98 , Table 1). There were no interactions between production system and year $(\mathrm{P}=$ 0.12 to 0.90$)$. Growing season stocking rates were higher on the native pastures in the Old World bluestem-Native system compared to the Native system, 50.5 versus 38.5 AUD ha $^{-1}$, but this increase did not affect plant populations. This may be attributable to the rest period of 51 days in the Old World bluestem-Native system while the steers grazed Old World bluestem in June and July.

Species that did not change in frequency over years included sand bluestem, switchgrass, little bluestem, sand lovegrass, sand paspalum, and purple threeawn. All of these are warm-season grasses and all except purple threeawn would be considered palatable decreasers. Populations of dominant warm-season grasses on the central and southern Great Plains have generally not been affected or have increased slightly with intensive early stocking (Owensby et al. 1988, Olson et al. 1993, Gillen and Sims 1999). Perennial threeawn increased moderately as stocking rates were reduced in west central Oklahoma but its reaction to grazing has been mixed in other studies (Gillen et al. 2000).

Sideoats grama, sand dropseed, fall witchgrass, sand sedge, windmillgrass, blue grama, sandbur, and sand sagebrush all increased over years, regardless of treatment (Table 1). All are warm-season species except sand sedge. Sandbur is a warm-season annual grass that may have

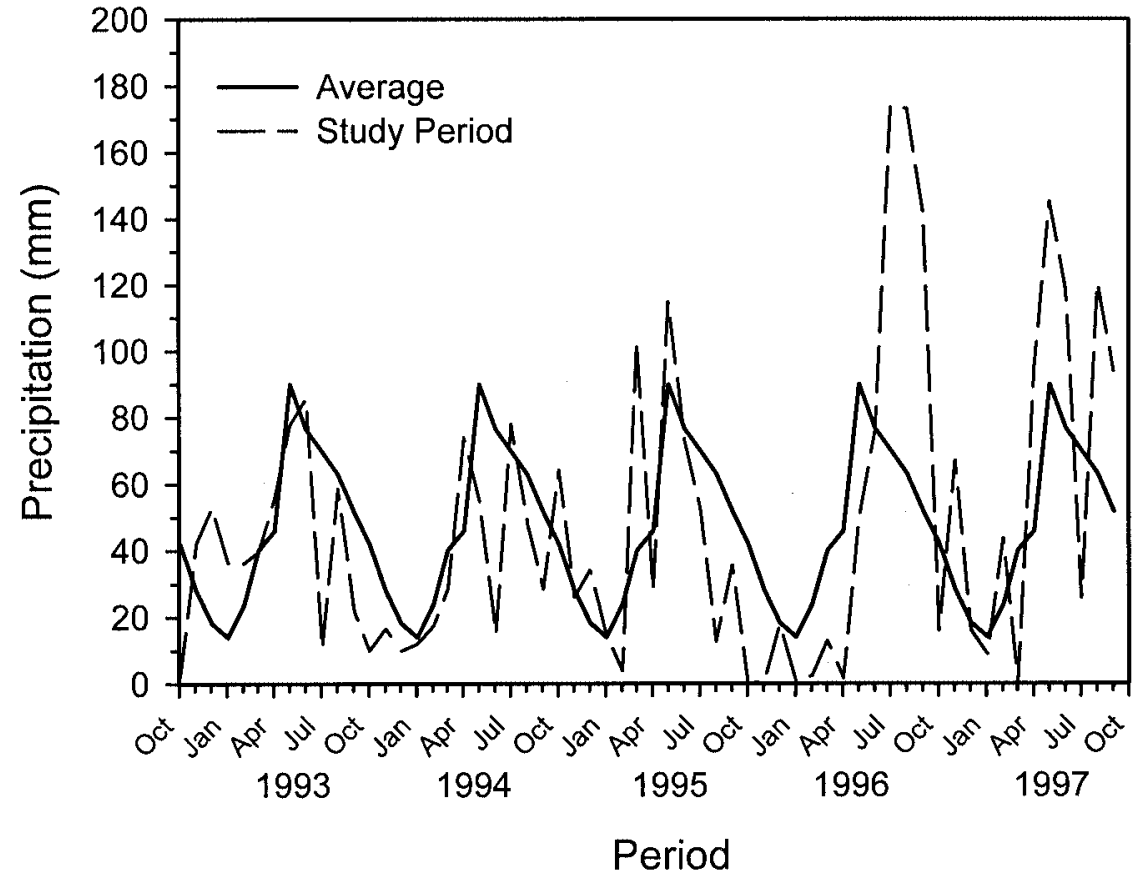

Fig. 1. Precipitation at the Southern Plains Experimental Range, Harper County, Okla., during the study period. Average precipitation calculated over the period 1940 to 1998.

responded to abundant precipitation in July and August of 1996.

Species decreasing over years included Texas bluegrass, Scribner's dicanthelium, western ragweed, annual buckwheat, camphorweed, and plantago. Texas bluegrass and Scribner's dicanthelium are both coolseason grasses and their decrease may be a reflection of the severe winter-spring drought just prior to the second sample period. This drought was probably also responsible for the decreases in forb species. Three of these species, annual buckwheat, camphorweed, and plantago, are annuals and susceptible to adverse spring growing conditions. Camphorweed and plantago were essentially absent in the second sample (Table 1).

\section{Old World Bluestem Standing Crop}

Standing crop of Old World bluestem was similar $(\mathrm{P}=0.16)$ for WW-Iron Master $\left(4,790 \pm 1,350 \mathrm{~kg} \mathrm{ha}^{-1}\right)$ and WWSpar $\left(4,480 \pm 1,190 \mathrm{~kg} \mathrm{ha}^{-1}\right)$ when averaged over years. There was no interaction between variety and year $(\mathrm{P}=0.80)$ indicating a consistent response over years. WW-Iron Master produces about $50 \%$ more forage than WW-Spar when growing on calcareous, iron-deficient soils (Berg et al. 1986).

The average peak standing crop over years and cultivars was $4,640 \mathrm{~kg} \mathrm{ha}^{-1}$. Old World bluestem standing crop was affected by year $(\mathrm{P}<0.01)$ ranging from a low of $3,200 \pm 548 \mathrm{~kg} \mathrm{ha}^{-1}$ in 1997 to a high of $6,270 \pm 620 \mathrm{~kg} \mathrm{ha}^{-1}$ in 1996 when averaged over cultivars. Gillen et al. (1999) measured peak standing crops of $4580 \mathrm{~kg}$ $\mathrm{ha}^{-1}$ for WW-Iron Master growing on an Enterprise fine sandy loam (coarse-silty, mixed, thermic Typic Ustochrept). Berg (1990, 1993) reported annual production of 2,840 kg ha-1 for WW-Spar growing on a Woodward sandy loam (coarse-silty, mixed, thermic Typic Ustocrept) in this same region and 2,945 $\mathrm{kg} \mathrm{ha}^{-1}$ from WWIron Master growing on a Carey loam (fine silty, mixed, thermic, Typic Argiustoll). Precipitation in the May to August period was $5-30 \%$ above average for all of these studies and nitrogen fertilizer rates were comparable. The maximum production potential for these grasses may be higher than previously thought.

\section{Steer Gain}

Winter gains were greater for steers on native pastures compared with those on Old World bluestem (Table 2). This resulted in average daily gains of $0.34 \mathrm{~kg}$ head $^{-1}$ day $^{-1}$ for steers on the Native system and $0.19 \mathrm{~kg} \mathrm{head}^{-1} \mathrm{day}^{-1}$ for steers on Old World bluestem. Stocking density was 16 times higher in the Old World bluestem pastures. Forage standing crop was not measured but was probably no more than 3 to 4 times higher in the Old World bluestem pastures. This resulted in a higher grazing pressure in the Old World 
Table 1. Plant frequency (\%) in rangeland pastures as affected by production system and year and P-values from analyses-of-variance.

\begin{tabular}{|c|c|c|c|c|c|c|}
\hline \multirow[b]{2}{*}{ Species } & \multirow{2}{*}{$\begin{array}{l}\text { Production } \\
\text { System }\end{array}$} & \multicolumn{2}{|c|}{ Plant Frequency } & \multicolumn{3}{|c|}{ P-values } \\
\hline & & 1993 & 1996 & Treatment & Year & Trt xYear \\
\hline \multirow{2}{*}{$\begin{array}{l}\text { Sand bluestem } \\
\text { (Andropogon hallii Hack.) }\end{array}$} & & \multicolumn{2}{|c|}{-} & & & \\
\hline & Native & 21.7 & 28.8 & 0.79 & 0.30 & 0.60 \\
\hline \multirow{2}{*}{$\begin{array}{l}\text { Switchgrass } \\
\quad \text { (Panicum virgatum L.) }\end{array}$} & Native & 16.0 & 18.8 & 0.56 & 0.34 & 0.60 \\
\hline & OWB-Native & 11.8 & 14.1 & & & \\
\hline \multirow{2}{*}{$\begin{array}{l}\text { Little bluestem } \\
\quad \text { [Schizachyrium scoparium (Michx.) Nash] }\end{array}$} & Native & 11.7 & 12.5 & 0.98 & 0.33 & 0.83 \\
\hline & OWB-Native & 11.0 & 13.5 & & & \\
\hline \multirow{2}{*}{$\begin{array}{l}\text { Sand paspalum } \\
\text { (Paspalum setaceum Michx.) }\end{array}$} & Native & 10.5 & 13.5 & 0.24 & 0.16 & 0.38 \\
\hline & OWB-Native & 17.0 & 20.9 & & & \\
\hline \multirow{2}{*}{$\begin{array}{l}\text { Sideoats grama } \\
\text { [Bouteloua curtipendula (Michx.) Torr.] }\end{array}$} & Native & 6.7 & 7.5 & 0.68 & 0.06 & 0.37 \\
\hline & OWB-Native & 2.9 & 7.3 & & & \\
\hline \multirow{2}{*}{$\begin{array}{l}\text { Sand dropseed } \\
\text { [Sporobolus cryptandrus (Torr.) Gray] }\end{array}$} & Native & 40.3 & 47.0 & 0.90 & 0.09 & 0.42 \\
\hline & OWB-Native & 38.3 & 47.8 & & & \\
\hline $\begin{array}{l}\text { Texas bluegrass } \\
\text { (Poa arachnifera Torr.) }\end{array}$ & OWB-Native & 51.9 & 29.3 & & & \\
\hline \multirow{2}{*}{$\begin{array}{l}\text { Sand sedge } \\
\text { (Cyperus schweinitzii Torr.) }\end{array}$} & Native & 6.9 & 28.5 & 0.98 & 0.01 & 0.52 \\
\hline & OWB-Native & 6.7 & 28.9 & & & \\
\hline \multirow{2}{*}{$\begin{array}{l}\text { Scribner's dicanthelium } \\
\text { [Dicanthelium oligosanthes (J.A. Schultes) Gould] }\end{array}$} & Native & 7.4 & 5.0 & 0.74 & 0.06 & 0.13 \\
\hline & OWB-Native & 6.7 & 4.4 & & & \\
\hline \multirow{2}{*}{$\begin{array}{l}\text { Windmillgrass } \\
\text { (Chloris verticillata Nutt.) }\end{array}$} & Native & 11.0 & 19.0 & 0.30 & 0.01 & 0.61 \\
\hline & OWB-Native & 4.4 & 16.0 & & & \\
\hline \multirow{2}{*}{$\begin{array}{l}\text { Blue grama } \\
\text { [Bouteloua gracilis (Willd. ex Kunth) Lag. ex Griffiths] }\end{array}$} & Native & 54.9 & 69.0 & 0.96 & 0.01 & 0.17 \\
\hline & OWB-Native & 50.3 & 70.1 & & & \\
\hline \multirow{2}{*}{$\begin{array}{l}\text { Sandbur } \\
\text { (Cenchrus carolinianus Walt.) }\end{array}$} & Native & 7.2 & 21.5 & 0.16 & 0.01 & 0.33 \\
\hline & OWB-Native & 16.7 & 38.5 & & & \\
\hline \multirow{2}{*}{$\begin{array}{l}\text { Western ragweed } \\
\text { (Ambrosia psilostachya DC.) }\end{array}$} & Native & 72.5 & 4.3 & 0.26 & 0.01 & 0.69 \\
\hline & OWB-Native & 64.6 & 1.9 & & & \\
\hline $\begin{array}{l}\text { Annual buckwheat } \\
\text { (Eriogonum annuum Nutt.) }\end{array}$ & Native & 7.9 & 1.8 & 0.72 & 0.07 & 0.51 \\
\hline
\end{tabular}

bluestem pastures that reduced the opportunity for selective grazing. Selectivity was also favored in the native pastures by the greater variety of plant species present. Marston et al. (1993) found crude protein content of steer diets was higher in native pastures compared to Old World bluestem during this period but in vitro organic matter digestibility was higher in Old World bluestem pastures. Winter gains did not differ between the 2 cultivars of Old World bluestem (Table 2).

Steers in both production systems grazed native pasture in the Early Native management period. Steers in the Native system again gained more weight than steers in the Old World bluestem-Native system (Table 2). This resulted in respective average daily gains of 0.85 and 0.70 kg head ${ }^{-1}$ day $^{-1}$ from the 2 systems. Although steers in both systems were grazing the same pasture type, the stocking density for steers in the Native system was one-half the stocking density of steers in the Old World bluestem-Native system. Steer gains are often less sensitive to stocking density during the spring period because forage quality is uniformly high (Owensby et al. 1988, Olson et al. 1993). However, earlier studies of intensive early stocking at this same location also reported reduced steer growth when stocking densities were increased in the early portion of the growing season (Gillen and Sims 1999).

The steers grazed different forage types during the Old World bluestem management period. Gains for Native steers were less than for Old World bluestem-Native steers (Table 2). Average daily gains for steers grazing native pasture, WW-Iron Master, and WW-Spar, were 0.89, 1.09, and $0.94 \mathrm{~kg}$ head $^{-1}$ day $^{-1}$. Forage quality was likely higher in the Old World bluestem pastures during this period. The dominant warm-season native grasses had been growing rapidly for about 4 weeks when this management period began while the Old World bluestems were just beginning rapid vegetative growth. In addition, the Old World bluestems were fertilized with nitrogen, which has been shown to increase forage crude protein content (Berg and Sims 1995). Diets of steers grazing nitrogen-fertilized Old World bluestem were higher in crude protein and in vitro organic matter digestibility than diets of steers grazing native pasture during June and August in west-central Oklahoma (Gunter et al. 1992).

Steers grazing WW-Iron Master gained more than steers grazing WW-Spar during the Old World bluestem management period (Table 2). On 7 sample dates over 3 years, Sims et al. (1983) reported that WW-Iron Master was always higher than or equal to WW-Spar in crude protein content with an overall mean of $8.0 \%$ for WW-Iron Master and 7.6\% for WW-Spar. 
Table 2. Individual steer gain for different management periods. Average dates: a) Winter, 21 Dec. to 15 Mar.; b) Early Native, 15 Mar. to 9 Jun.; c) Old World Bluestem, 9 Jun. to 30 Jul.; and d) Late Native, 30 Jul. to 31 Aug. All steers grazed native pastures during the Early and Late Native periods. Steers in the Old World bluestem-Native systems grazed Old World bluestem during the Winter and Old World bluestem periods. Numbers in parentheses represent 1 standard deviation.

\begin{tabular}{|c|c|c|c|c|c|}
\hline \multirow[b]{2}{*}{ Production system } & \multicolumn{5}{|c|}{ Management period } \\
\hline & Winter & Early native & Old World bluestem & Late native & Total \\
\hline Native & $\begin{array}{c}-\ldots-\cdots \\
28 \\
(10)\end{array}$ & $\begin{array}{c}74 \\
(19)\end{array}$ & $\begin{array}{c}4 \ldots \\
45 \\
\text { (5) }\end{array}$ & $\begin{array}{c}14 \\
(10)\end{array}$ & $\begin{array}{l}-\cdots-. \\
161 \\
(22)\end{array}$ \\
\hline 'WW- Iron Master' - Native & $\begin{array}{l}17 \\
(7)\end{array}$ & $\begin{array}{c}62 \\
(24)\end{array}$ & $\begin{array}{l}56 \\
(5)\end{array}$ & $\begin{array}{c}18 \\
(10)\end{array}$ & $\begin{array}{l}152 \\
(19)\end{array}$ \\
\hline 'WW- Spar' - Native & $\begin{array}{l}15 \\
(9)\end{array}$ & $\begin{array}{c}59 \\
(23)\end{array}$ & $\begin{array}{l}48 \\
(6)\end{array}$ & $\begin{array}{l}22 \\
(8)\end{array}$ & $\begin{array}{l}144 \\
(23)\end{array}$ \\
\hline$\underline{\mathrm{P}-V a l u e s}$ for contrasts & & & & & \\
\hline $\begin{array}{l}\text { Native vs. Old World bluestem Systems } \\
\text { Old World bluestem cultivars }\end{array}$ & $\begin{array}{l}<0.01 \\
0.38\end{array}$ & $\begin{array}{l}0.03 \\
0.34\end{array}$ & $\begin{array}{l}<0.01 \\
<0.01\end{array}$ & $\begin{array}{l}0.25 \\
0.15\end{array}$ & $\begin{array}{l}0.05 \\
0.14\end{array}$ \\
\hline
\end{tabular}

WW-Iron Master also had greater or equal in vitro dry matter digestibility on 6 of 7 dates with an overall mean of $62.6 \%$ for WW-Iron Master and $61.4 \%$ for WW-Spar (Sims et al. 1983). This advantage in nutrient concentration may explain the higher steer gains on WW-Iron Master.

For the final management period, Late Native, all steers were again on native pasture. There was no difference in steer gains for Native or Old World bluestemNative steers (Table 2) or between steers that had grazed on the different cultivars of Old World bluestem (Table 2). Average daily gains were 0.45 and $0.62 \mathrm{~kg} \mathrm{head}^{-1}$ $\mathrm{day}^{-1}$ for the Native and Old World bluestem-Native systems, respectively. There were no interactions for steer gain $(\mathrm{P}>0.08)$ between production system and year for any management period.

Total gains over all management periods averaged $13.5 \mathrm{~kg}$ head $^{-1}$ greater for the Native system (Table 2) over the Old World bluestem-Native system and did not differ between sub-systems of Old World bluestem-Native. This difference was attributable to the Winter period when gains were $12 \mathrm{~kg} \mathrm{head}^{-1}$ higher for the Native system. Growing season gains (combined over the last 3 management periods) were not different between production systems $(P=0.70)$. Winter gain was only $13 \%$ of total gain but was important in subsequent economic analyses.

Livestock production per ha from the native portion of each system was not different ( $\mathrm{P}=0.89$, Fig. 2$)$. To increase gain per ha on native pasture, stocking rate must usually be increased because gain per head is near maximum under moderate stocking rates. With the ratio of native:Old World bluestem used in this study, stocking rate for the native pasture in the Old World bluestem-Native system actually decreased $5 \%$ below moderate stocking rates so there was little potential to increase gain per ha. With an overall mean of $47 \mathrm{~kg} \mathrm{ha}^{-1}$, the gains from native pasture are similar to the $42 \mathrm{~kg} \mathrm{ha}^{-1}$ reported from earlier stocking rate studies at this location (Sims and Gillen 1999).

Production per ha was not different between cultivars of Old World bluestem within the Old World bluestem-Native systems ( $\mathrm{P}=0.17$, Fig. 2 ) or for the total system area $(P=0.69)$. Gain per ha was about 6.5 times higher on Old World bluestem than native pasture. At $306 \mathrm{~kg}$ $\mathrm{ha}^{-1}$, gains from Old World bluestem were not greatly different than the $270 \mathrm{~kg} \mathrm{ha}^{-1}$ reported from earlier work at this same location (Berg and Sims 1995, Gillen et al. 1999). The value of using Old World

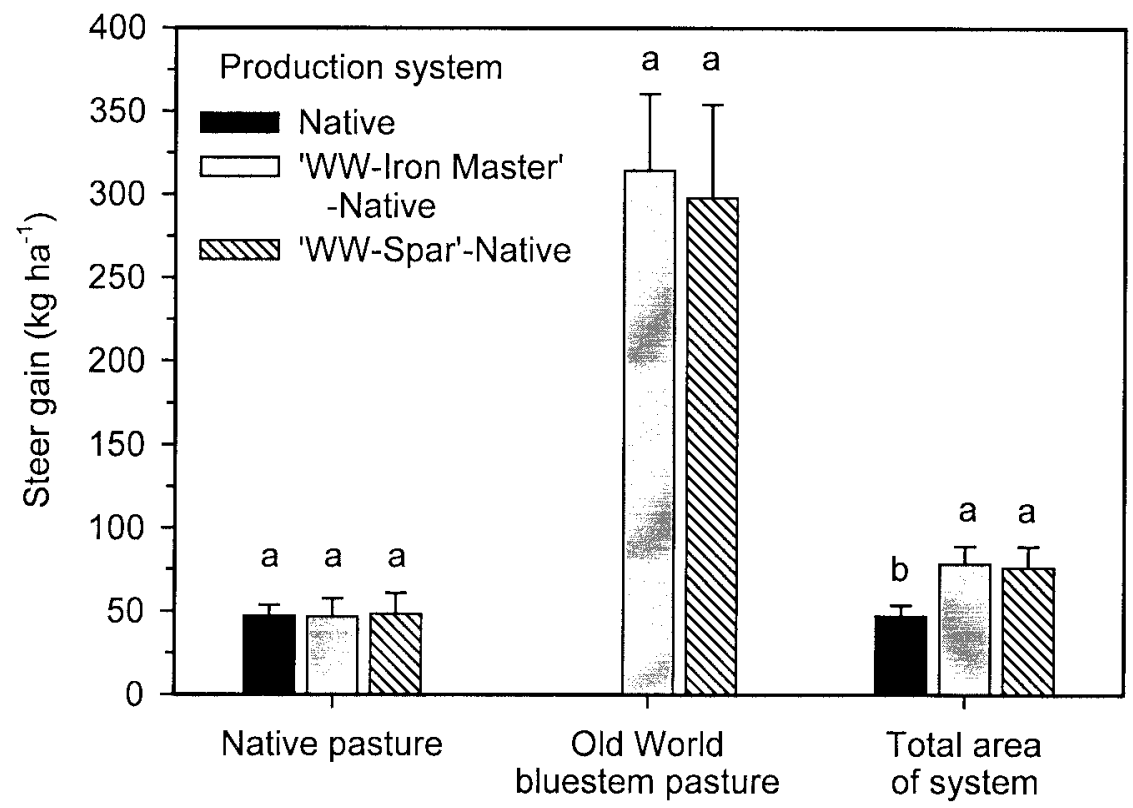

Fig. 2. Livestock production from the different forage types and the total land area in the 2 production systems. Within forage type, production systems with different letters are significantly different $(P<0.05)$. Bars denote 1 standard deviation. 


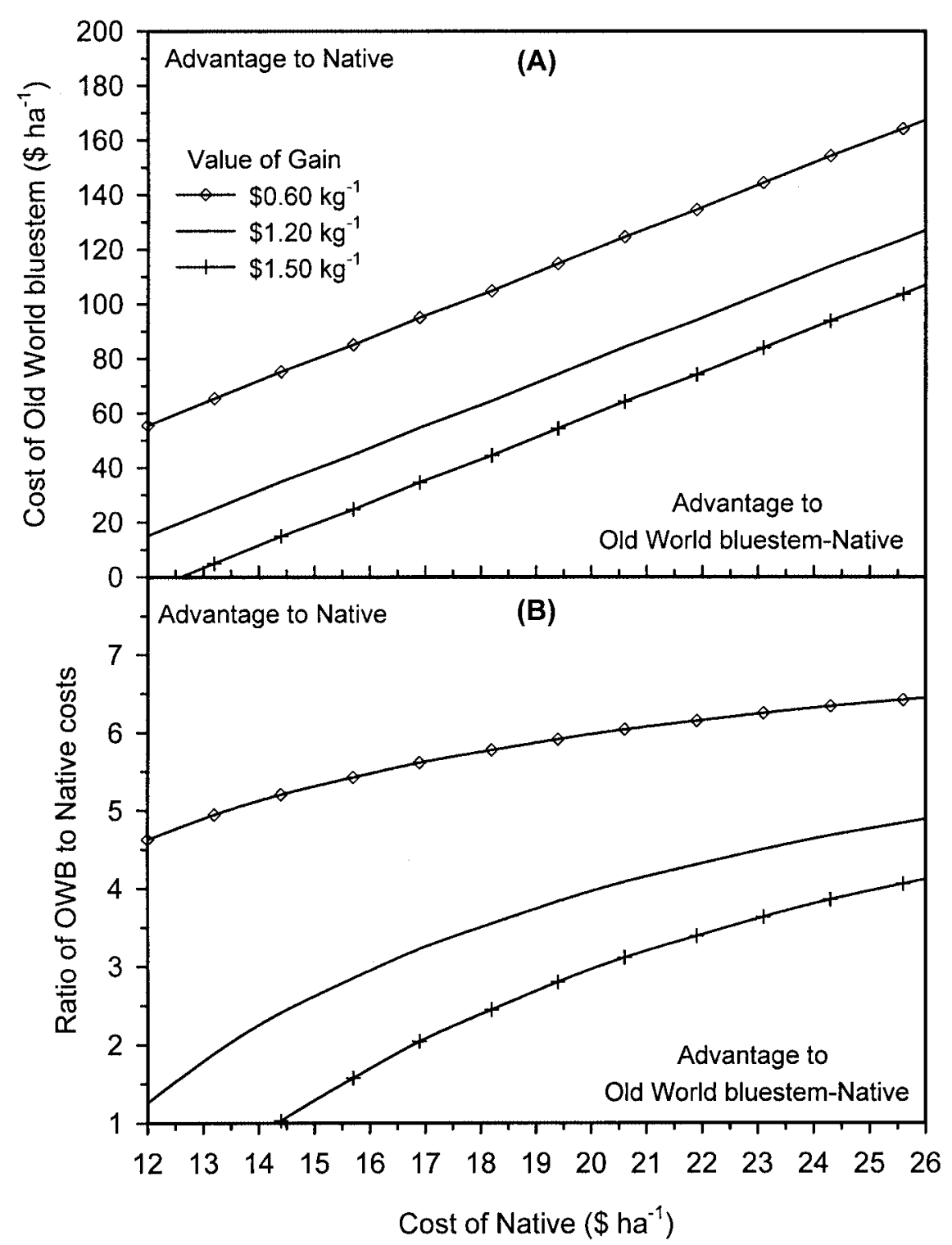

Fig. 3. Relative economic returns between the Native and Old World bluestem-Native production systems. A) The effects of value of gain and land costs. B) The effects of value of gain and ratio of land costs. The lines represent equal returns between the 2 systems. The Native system has greater net returns in the upper left portion of the figures and the Old World bluestem-Native system has greater economic returns in the lower right portion of the figures.

Total system stocking rate was 53 AUD $\mathrm{ha}^{-1}$ in the Native system compared to 90 AUD $\mathrm{h}^{-1}$ in the Old World bluestemNative system, an increase of $69 \%$ for the complementary system.

\section{Economic Comparisons}

The relative economic response between systems was dependent on the management costs for the 2 forage types. To frame the following discussion, regional rental rates for native pasture averaged $\$ 16.70 \mathrm{ha}$ ${ }^{1}$ with a range of $\$ 2.50$ to $\$ 37.0$ ha $^{-1}$ (Doye et al. 1999). Regional rental rates for Old World bluestem pasture averaged $\$ 27.70$ were 0.75 to 66.5 . The average ratio was 3.7 .

The cost of Old World bluestem that maintained equal returns between production systems was linearly and positively related to the cost of native pasture (Fig. $3 \mathrm{~A})$. As the cost of native pasture increased, the cost of Old World bluestem could also increase and still maintain equal returns. For each $\$ 1 \mathrm{ha}^{-1}$ increase in the cost of native pasture, Old World bluestem could increase $\$ 8$ ha $^{-1}$ because 1 ha of Old World bluestem substituted for 8 ha of native pasture in the Old World bluestem-Native system. At a value of gain of $\$ 1.20 \mathrm{~kg}^{-1}$ and a cost of native pasture of $\$ 17 \mathrm{ha}^{-1}$, returns were greater for the Old World bluestem-Native system only if the cost of Old World bluestem was less than 3.3 times the cost of native pasture (Fig. 3B). As the cost of native pasture increased, the competitive advantage increased for Old World bluestem. At a native pasture cost of $\$ 26 \mathrm{ha}^{-1}$, Old World bluestem could cost 4.9 times as much as native pasture.

As the value of gain increased, the economic penalty for lower steer gains in the Old World bluestem-Native production system also increased. This means a producer could not afford to pay as much for land costs for Old World bluestem in the Old World bluestem-Native system (Fig. $3 \mathrm{~A})$. Conversely, as the value of gain declined, the cost of Old World bluestem could increase. Higher values of gain (narrow price differentials) favor the Native system while lower values of gain (wide price differentials) favor the Old World bluestem-Native system. If native pasture costs $\$ 17 \mathrm{ha}^{-1}$ and value of gain is $\$ 1.50$ $\mathrm{kg}^{-1}$, returns are only greater for the Old World bluestem-Native system if the cost of Old World bluestem is less than $\$ 36 \mathrm{ha}^{-1}$ or 2.1 times greater than the cost of native pasture (Fig. 3B). However, if the value of gain is $\$ 0.60 \mathrm{~kg}^{-1}$, the cost of Old World bluestem can increase to $\$ 96 \mathrm{ha}^{-1}$ or 5.6 times the cost of native pasture. For each $\$ 0.01 \mathrm{~kg}^{-1}$ decrease in value of gain, the allowable cost of Old World bluestem increases $\$ 0.67 \mathrm{ha}^{-1}$. The ratio of allowable land costs was less sensitive to value of gain as the cost of native pasture increased (Fig 3B).

The lower season-long gain of $13.5 \mathrm{~kg}$ head $^{-1}$ in the Old World bluestem-Native system was a key factor in the analysis. At a value of gain of $\$ 1.20 \mathrm{~kg}^{-1}$, the ratio of land costs that equalizes net returns ranges from 1.3 to 5.2 . If steer gains had been similar between systems, the allowable ratio of land costs increases to 8 and is not 
dependent on value of gain. The Winter management period accounted for much of the difference in steer gains. One approach to improving gains for the Old World bluestem-Native system would be to put half the steers on native pasture during the Winter period. In this study, native pasture in the Old World bluestem-Native system was not utilized in the Winter period. Since the stocking density of steers on native pasture would be equal between the 2 production systems, gains should at least be equalized on half of the steers. With the resulting lower stocking density on Old World bluestem, gains might also improve for the steers still grazing Old World bluestem.

This economic analysis was based on relative returns between the 2 production systems. Actual profitability for either system depends on many other factors such as purchase and sales prices, marketing arrangements, death loss, feed costs, and many others. However, these factors would generally affect both systems. Given average values for livestock gain of $\$ 1.20 \mathrm{~kg}^{-1}$, and average costs for native pasture of $\$ 17 \mathrm{ha}^{-1}$, the Old World bluestem-Native system was economically competitive as long as the ratio of land costs was 3.3. Since the average ratio of land costs was 3.7 , the Native system was often more profitable, even though the livestock production per ha was much higher with the Old World bluestemNative system. Conditions further favoring the Native system included low costs for native pasture and a high marginal value of livestock gain. When value of gain is low, the Old World bluestem-Native system would likely be more profitable at almost any cost level for native pasture.

\section{Literature Cited}

Berg, W.A. 1990. Old World bluestem responses to nitrogen fertilization. J. Range Manage. 43:265-270.

Berg, W.A. 1993. Old World bluestem response to fire and nitrogen fertilizers. J. Range Manage. 46:421-425.

Berg, W.A. 1994. Sand sagebrush- mixed prairie, p. 99. In: T. N. Shiflet (ed.), Rangeland Cover Types of the United States. Soc. Range Manage., Denver, Colo.

Berg, W.A. and P.L. Sims. 1995. Nitrogen fertilizer use efficiency in steer gain on Old World bluestem. J. Range Manage. 48:465-469.

Berg, W.A., C.L. Dewald, and P.I. Coyne. 1986. Selection for iron-efficient Old World bluestems. J. Plant Nutr. 9:453-458.

Consortium. 1988. Guide for care and use of agricultural animals in agricultural research and teaching. Consortium for Developing a Guide for the Care and Use of Agricultural Animals in Agricultural Research and Teaching. Champaign, Ill.

Doye, D.G., D. Kletke, and B.L. Fischer. 1999. Oklahoma pasture rental rates: 1998-99. Okla. Coop Ext. Serv. Curr. Rep. CR-216.

Gillen, R.L. and P.L. Sims. 1999. Intensive early stocking of southern mixed grass prairie, USA, p. 499-500. In: Eldridge, D., and D. Freudenberger (eds.). Proc. $6^{\text {th }}$ International Rangeland Congress, Townsville, Australia.

Gillen, R.L., J.A. Eckroat, and F.T. McCollum III. 2000. Vegetation response to stocking rate in southern mixed-grass prairie. J. Range Manage. 53:471-478.

Gillen, R.L., W.A. Berg, C.L. Dewald, and P.L. Sims. 1999. Sequence grazing systems on the southern plains. J. Range Manage. 52:583-589.

Gunter, S.A., F.T. McCollum III, and R.L. Gillen. 1992. Midgrass prairie range versus Plains bluestem pasture for stocker cattle, $p$. 426-433. In: 1992 Animal Science Research Report. Okla. Agr. Exp. Sta. MP-136, Stillwater, Okla.
Kletke, D. and D.G. Doye. 1998. Oklahoma farm and ranch custom rates, 1997-98. Okla. Coop. Ext. Serv. Curr. Rep. CR-205.

Launchbaugh, J.L., C.E. Owensby, F.L. Schwartz, and L.R. Corah. 1978. Grazing management to meet nutritional and functional needs of livestock, p. 541-546. In: Hyder, D. N. (ed.), Proc. $1^{\text {st }}$ Int. Rangeland Congress, Denver, Colo.

Marston, T.T., S.A. Gunter, F.T. McCollum III, and R.L. Gillen. 1993. A comparison of midgrass prairie and Old World bluestem during winter and early spring, p. 363-366. In: 1993 Animal Science Research Report. Okla. Agr. Exp. Sta. P-933, Stillwater, Okla.

Milliken, G.A. and D.E. Johnson. 1984. Analysis of messy data. Lifetime Learning Publications, Belmont, Calif.

Olson, K.C., J.R. Brethour, and J.L. Launchbaugh. 1993. Shortgrass range vegetation and steer growth response to intensiveearly stocking. J. Range Manage. 46:127-132.

Owensby, C.E., R. Cochran, and E.F. Smith. 1988. Stocking rate effects on intensive-early stocked Flint Hills bluestem range. J. Range Manage. 41:483-487.

Sims, P.L. and D. Bailey. 1995. Calf production by Angus-Hereford and BrahmanHereford cows on two native rangeland forage systems. J. Anim.. Sci. 73:2893-2902.

Sims, P.L. and R.L. Gillen. 1999. Rangeland and steer responses to grazing in the southern plains. J. Range Manage. 52:651-660.

Sims, P.L., C.L. Dewald, and S. Cowles. 1983. Advancements with Old World bluestems, p. 4-11. In: Wiedemann, H. T., and J. F. Cadenhead (eds.). Proc. Range and Pasture Seeding in the Southern Great Plains. Texas A\&M Univ. Res. and Ext. Center, Vernon, Tex..

White, L.M. and C.L. Dewald. 1996. Yield and quality of WW-Iron Master and caucasian bluestem regrowth. J. Range Manage. 49:42-45 